\title{
A Study On Space Pattern And Traditional House Of Penglipuran Village
}

\section{Kajian Pola Ruang dan Rumah Tradisional Desa Penglipuran}

\author{
M. Maria Sudarwani ${ }^{1 *}$, Iwan Priyoga ${ }^{2}$ \\ Program Studi Arsitektur, Fakultas Teknik, Universitas Pandanaran ${ }^{1 *}$ \\ maria@unpand.ac.id \\ Program Studi Arsitektur, Fakultas Teknik, Universitas Pandanaran ${ }^{2}$
}

\begin{abstract}
:
Penglipuran Traditional Village is a traditional settlement in Bali which has an attractive space pattern seen from the order of the spatial pattern that is typical of the cultural activities of its people. The village is located at a distance of $45 \mathrm{~km}$ from Denpasar and $5 \mathrm{~km}$ from the capital city of Bangli Regency. The aim of the study was to find out the concept of traditional patterns of space and houses applied in Penglipuran Village, as a basis for researching traditional Balinese architecture. This research was conducted with qualitative descriptive method and case study approach. Penglipuran Village as a settlement has a space pattern which is divided into 3 (three) spatial arrangements based on the Tri Mandala concept consisting of: 1) Main Mandala (Pura); 2) Madya Mandala (Residence); 3) Nista Mandala (Tomb). The condition of the Penglipuran Traditional Village as a traditional mountain village shows one thing that stands out, namely the spread of settlement patterns tend to be linear because they are in mountainous areas. Penglipuran Bali Traditional House is an order of cultural result of the cultural mindset of the ancestors of the Penglipuran community in organizing an area well and upholding ancestral customs and striving to maintain the order well, neatly organized concept and sustainable nature and the surrounding environment.
\end{abstract}

Keywords: Kajian Pola Ruang, Rumah Tradisional, Desa Penglipuran

\section{PENDAHULUAN}

Di antara banyaknya desa adat yang tersebar di seluruh Indonesia, Desa Adat Penglipuran adalah salah satu desa adat yang masih bertahan dengan memiliki prinsip ekologis dalam adat dan budaya masyarakatnya. Desa Adat Penglipuran secara administratif terletak di wilayah Kelurahan Kubu, Kecamatan Bangli, Kabupaten Bangli Provinsi Bali. Lokasi desa ini terletak pada jarak $45 \mathrm{~km}$ Kota Denpasar, memiliki luas 112 ha yang terdiri dari tegalan, hutan bambu, permukiman, dan beragam fasilitas lainnya. Berada di ketinggian $700 \mathrm{~m}$ dpl yang menjadikan Penglipuran cukup berhawa sejuk, bebas dari kendaraan.

Desa Penglipuran ini dapat dicapai dari sisi timur melalui jalan raya Bangli-Kintamani, setelah sampai di Desa Kubu belok ke kiri dan dari sisi utara melalui jalan KintamaniKayuamba Bangli. Adapun batas-batas wilayah Desa Penglipuran adalah: 1) Sebelah utara berbatasan dengan Desa Adat Kayang; 2) Sebelah timur berbatasan dengan Desa Adat Kubu; 3) Sebelah selatan berbatasan dengan Desa Adat Cempaga; 4) Sebelah barat berbatasan dengan Desa Adat Cekeng. Desa Adat Penglipuran terhubung dengan jalan kolektor menuju pusat Kota Bangli sehingga memudahkan akses penduduk desa menuju kota yang berjarak kurang lebih $5 \mathrm{~km}$.

Pola tata ruang Desa Adat Penglipuran dibagi menjadi 3 bagian besar yang memisahkan kepentingn-kepentingan yang berdasarkan kegiatan masyarakat Desa Penglipuran khususnya dalam bidang upacara keagamaan (yadnya) yang disesuaikan dengan konsep Tri 
Hita Karana. Hal tersebut merupakan salah satu fungsi dari pola tata ruang di Desa Adat Penglipuran. Dengan konsep Tri Hita Karana pada pola tata ruang Desa Adat Penglipuran, akan terjalin hubungan yang harmonis antara manusia dengan Tuhan, Manusia dengan Manusia, Manusia dengan Lingkungan. Pola penataan ruang dan tata letak bangunan tradisional Desa Penglipuran menggunakan Pola Dasar Nawa Sanga, yaitu penggabungan orientasi antara gunung dan laut (UtaraSelatan), serta terhadap peredaran matahari (Timur-Barat). Nilai ruang utama pada sumbu bumi berada pada daerah utara (gunung) dan nilai ruang nista pada daerah selatan (laut), sedangkan nilai ruang utama pada sumbu religi berada pada daerah timur (matahari terbit) dan nilai ruang nista berada pada daerah barat (matahari terbenam). Ciri yang menonjol adalah adanya as Utara-Selatan (kaja-kelod) dengan pola linier yang berfungsi sebagai open space untuk kegiatan bersama dan membagi desa menjadi dua bagian permukiman warga yang saling berhadapan, sisi Timur dan Barat, dengan nilai ruang utama pada sumbu religi berada di timur (matahari terbit) dan nilai ruang nista berada di barat (matahari terbenam).

Open space Desa Adat Penglipuran menanjak menuju ke arah gunung (utara) dimana terdapat bangunan suci dengan orientasi ke Gunung Batur. Pola tata ruang dan tata letak bangunan rumah di Desa Adat Penglipuran pada umumnya mengikuti Pola Tri Mandala. Desa Adat Penglipuran memiliki potensi budaya yang sampai saat ini tetap terpelihara dengan baik. Potensi paling unik yang dimiliki adalah pola ruang dan arsitektur bangunan tradisional Bali khas Penglipuran. Pola ruang simetris dengan open space linier di tengah disertai pintu gerbang (angkul-angkul) seragam serta tata letak bangunannya merupakan pemandangan suasana pedesaan yang sangat unik, khas dan menarik untuk dinikmati. Adat istiadat yang menyertainya juga cukup unik dan beberapa hal berbeda dengan kebanyakan adat pedesaan di Bali.

Berdasarkan latar belakang diatas, rumusan masalahnya adalah sebagai berikut : 1) Apa yang mendasari terbentuknya pola ruang desa adat penglipuran; 2) Bagaimana arsitektur rumah tradisional Penglipuran?

\section{METODE}

Penelitian ini dilakukan dengan metode deskriptif kualitatif dengan pendekatan studi kasus. Metode penelitian deskriptif kualitatif ini dibuat dengan maksud untuk mengetahui konsep pola ruang dan rumah adat yang direncanakan di Desa Penglipuran Bali. Pendekatan studi kasus dipakai untuk memahami fenomena tertentu di suatu tempat tertentu dan waktu yang tertentu pula. Metode pengumpulan data yang digunakan dengan melakukan survey pada lokasi penelitian dan observasi, yaitu melakukan interaksi dengan melihat objek/subjek yang ada di lapangan, melihat dan membaca arsip, seperti halnya: membaca peta, melihat foto, membaca buku/jurnal, dan lain-lain. Sedangkan metode analisis data yang digunakan untuk mengungkap temuan adalah analisis data kualitatif.

\section{ANALISIS DAN INTERPRETASI}

Dalam konsep tata ruang Bali penataan lingkungan dan penempatan bagian-bagian rumah selalu berkiblat ke arah utara, hal ini dipengaruhi oleh Gogohan Tua (kebudayaan tua) yang menempatkan arah utara sebagai tempat tertinggi dan suci, sehingga pola penempatan bangunan desa selalu melintang dari utara ke selatan, dengan utara sebagai bagian suci. Sedangkan dalam tata ruang bangunan tinggal di Bali secara umum memiliki konsep sanga mandala, dimana sebuah bangunan terbagi menjadi bagian utama, madya dan nista. Konsep ini mengacu kepada dua hal, yaitu: 1) Arah lintasan matahari (timur-barat), dimana bagian bangunan timur lebih mulia dibanding bagian barat; 2) Sumbu kaja kelod (gunung laut), dimana arah gunung lebih mulia ketimbang arah laut.

\subsection{Pola Ruang Desa Penglipuran}

Pola tata ruang desa adat penglipuran dibagi menjadi 3 bagian besar yang memisahkan kepentingn-kepentingan yang berdasarkan kegiatan-kegiatan masyarakat Desa Penglipuran khususnya dalam bidang upacara keagamaan (yadnya). Hal tersebut disesuaikan dengan konsep Tri Hita Karana, yang dalam agama hindu Tri Hita Karana artinya tiga penyebab kebahagian dan keharmonisan manusia. Hal tersebut merupakan salah satu 
fungsi dari pola tata ruang di desa Adat Penglipuran Bangli.

Dengan konsep Tri Hita Karana pada pola tata ruang Desa Adat Penglipuran, akan terjalin hubungan yang harmonis antara manusia dengan Tuhan, Manusia dengan Manusia, Manusia dengan Lingkungan, adapun bagan yang menyatakan proses hubungan tersebut adalah sebagai berikut :

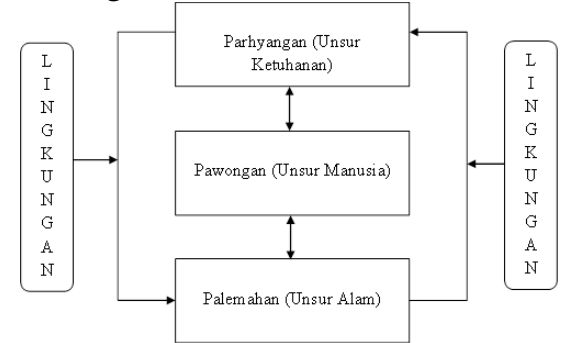

Gambar 1. Hubungan antara Komponen Tri Hita Karana

Berdasarkan bagan diatas, seluruh komponen yang ada mempunyai peranan yang sangat penting dalam mengharmoniskan kehidupan masyarakat di Desa Penglipuran Bangli. Di Desa Penglipuran saling menjaga keselarasan hubungan baik dengan Tuhan, Manusia, maupun lingkungan, hal tersebut dilakukan dalam upaya untuk mewujudkan keharmonisan yang sejati.

Adapun kegiatan yang dilakukan oleh masyarakat Desa Penglipuran dalam upaya untuk menjagakeharmonisan tersebut adalah sebagai berikut: a) Parhyangan/Unsur Ketuhanan; Pada komponen yang pertama yaitu parhyangan, masyarakat Desa Adat Penglipuran senantiasa melaksanakan Upacara Dewa Yadnya. Dimana upacara tersebut dilaksanakan pada tingkatan Utama Mandala, yaitu tingkatan yang paling tinggi yang letaknya ada di Wilayah Desa Bagian Utara. Di Uatama Mandala tersebut terdapat tempat suci berupa Pura Penataran yang menjadi tempat melaksanakan upacara dewa yadnya. b) Pawongan/Unsur Manusia; Dalam agama hindu memperhatikan pembinaan keluarga mulai dari terbentuknya janin sampai meninggal penuh dengan upacara adat dan agama. Dalam hal ini adalah upacara Manusa dan Fitra Yadnya, dimana kegiatan tesebut dilaksanakan di Madya Mandala untuk manusa yadnya dan di Nista Mandala untuk fitra yadnya. Selain hal tersebut dalam menjaga keharmonisan antara manusia, masyarakat Desa Penglipuran juga melaksanakan kegiatan gotong royong di dalam berbagai kegiatan desa. Hal tersebut dilaksanakan adalah untuk menumbuhkan rasa kekeluargaan dan rasa saling memiliki. c) Palemahan / Unsur Alam; Dalam masalah lingkungan, masyarakat desa penglipuran selalu menjaga kebersihan dan keasrian lingkungan yang ada di wilayah desa. Selain itu, berkaitan arsitektur bangunan masyarakat juga tetap menjaga keaslian dari arsitektur bangunan rumah dan pekarangan mereka sesuai dengan pola Tri Hita Karana. Hal tersebut dilakukan agar dapat menjaga kelestarian dari peninggalan leluhur berupa arsitektur bangunan sesuai dengan bangunan bali kuno.

Perwujudan pola dan struktur ruang tradisional Bali dilatar belakangi oleh alam pikiran keagamaan khususnya agama Hindu yaitu: 1) Tattwa (filosofi); 2) Tata susila (etika); 3) Upacara (ritual). Dengan adanya tatanan konsep, orientasi ruang dalam yaitu aspek tata susila (etika), memisahkan ruang-ruang yang bersifat suci/sakral dengan fungsi kegiatan non suci, maka pola tata ruang permukiman Desa Adat Penglipuran terdiri dari dua utama, yaitu: Konsep arah orientasi, arah mata angin dan Konsep sumbu religi, Tri Mandala. Nilai ruang utama pada sumbu bumi berada pada daerah utara (gunung) dan nilai ruang nista pada daerah selatan (laut), sedangkan nilai ruang utama pada sumbu religi berada pada daerah timur (matahari terbit) dan nilai ruang nista berada pada daerah barat (matahari terbenam). Akibat dari penerapan konsep sumbu bumi dan sumbu matahari pada tatanan permukiman desa adatnya, maka morfologi Desa Adat Penglipuran berbentuk linear dengan jalan.

Pola linear pada pemukiman Desa Penglipuran dengan sistem pembagian Tata Ruang horisontal bersumbu gunung dan laut dengan orientasi arah mata angin dengan sumbu Kaja (utara) atau Gunung, dan Kelod (selatan) atau laut. Dalam pembagian peruntukan lahan (tata ruang), Desa Penglipuran menganut konsep Tri Angga yang dalam bhuana agung sering disebut dengan Tri Loka atau disebut Tri Mandala (Acwin; 2008).Tri Mandala, yakni sebuah sistem penataan ruang yang dibagi menjadi tiga zona peruntukan. Istilah tersebut berasal dari dua kata, yakni Tri yang berarti tiga dan Mandala yang berarti ruang. Adapun pembagian tata ruang berdasarkan konsep Tri 
Mandala adalah terdiri dari: 1) Utama Mandala (Ulu); bagian utara desa bagian paling suci berupa sanggah. Zona ini merupakan tempat yang memiliki nilai tertinggi di antara zona yang lain. Terletak di bagian yang paling dekat dengan Gunung (di kawasan Desa Penglipuran, zona Utama berada di bagian Utara). Di zona ini terdapat sebuah Pura sebagai tempat peribadatan pusat dari seluruh warga Desa Penglipuran. Menurut Tribinuka (2017: hal.73) Pura dalam bahasa Sanskerta berarti 'kota', dalam perkembangannya istilah pura dipergunakan untuk tempat persembahyangan. Pada zona Utama Mandala ini terdapat tempat suci yang terdiri dari Pura Penataran, Pura Puseh, Pura Dukuh, Pura Rambut Sedana, Pura Empu Aji dan Pura Empu Nalwah. 2) Madya Mandala (Tengah); bagian tengah desa tempat kegiatan dan aktifitas keluarga sehari-hari. Merupakan zona yang memiliki nilai di tengahtengah. Terletak di antara zona Utama dan Nista. Di zona Madya Mandala ini merupakan pemukiman warga masyarakat tempat didirikannya rumah tinggal bagi penduduknya. Rumah utama yang berada di zona ini berjumlah 76 rumah yang dibagi menjadi oleh jalan utama menjadi 32 rumah di tiap sisi jalan. Penomoran rumah menggunakan sistem modern, nomor ganjil berada di satu sisi yaitu di sisi timur jalan dan nomor genap berada di sisi lain yaitu di sisi barat jalan. Pada zona Madya Mandala ini terdapat beberapa pura milik desa dan dadia, seperti Pura Ratu Pingit, Pura Balai Banjar, Pura Dalem Tampuagan, Tugu Pahlawan. 3) Nista Mandala (Teben); bagian selatan bagian belakang (teben) pekarangan. Zona ini merupakan tempat yang memiliki nilai terendah di antara zona yang lain. Terletak di bagian yang paling dekat dengan laut (di kawasan Desa Penglipuran, zona Nista berada di bagian Selatan). Karena itu, di zona ini terdapat sebuah kompleks pemakaman. Pada zona Nista Mandala ini terdapat beberapa pura seperti Pura Dalem (Pura Pelapuhan), Pura Dalem Pingit, Pura Mas Ayu Manik Melasem dan Pura Ratu Tungkup.

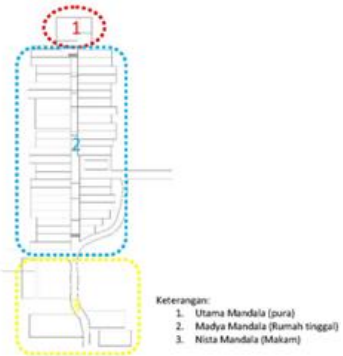

Gambar 2. Pembagian Tata Ruang Desa Panglipuran

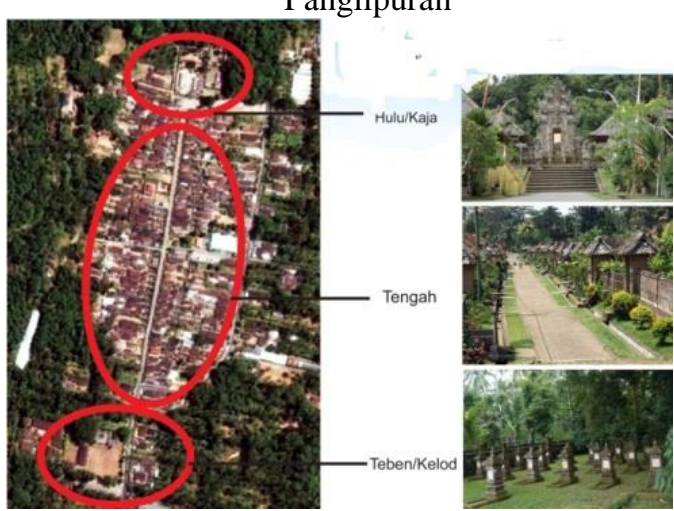

Gambar 3. Pembagian Tata Ruang Desa Panglipuran

Desa Penglipuran berorientasi ke gunung "kaja" dan ke laut "kelod" yang membentuk pola linear yang membagi hunian menjadi dua bagian. Massa desa yang linear ini mengikuti sumbu axis utara-selatan dan mengikuti leveling (transis) yang ada. Tata nilai utama madya dan nista yang menggunakan analogi tubuh manusia yang disebut Tri Angga. Tri Angga atau Tri Loka merupakan konsep keseimbanagn konsep keseimbangan kosmologis yang dicetuskan oleh Empu Kuturan (Arrafiani; 2012). Tri Angga yaitu kepala, badan, dan kaki sekaligus yang terbentuk pada Desa Penglipuran yang notabene termasuk peninggalan jaman Bali Aga yang berpolakan gunung dan laut.

\subsection{Terbentuknya Pola Ruang Desa}

Pada dasarnya terbentuknya pola ruang suatu desa dapat terjadi karena kondisi geografis dimana desa tersebut terbentuk. Hal-hal yang mempengaruhi terbentuknya pola ruang karena kondisi geografis meliputi lokasi desa, ketersediaan air, kondisi topografi tanah, kondisi jalan dan sebagainya. Menurut R. Bintarto (1977) ada 3 pola keruangan suatu desa yaitu: a) Pola Memusat atau Nucleated, yaitu bentuk desa yang memiliki kenampakan yang 
cenderung memusat atau bertemu pada satu titik. Faktor yang memengaruhi pola ruang cenderung memusat tersebut diantaranya ketersediaan sumberdaya air dan kondisi tanah yang relatif subur. Pola keruangan desa yang memusat paling banyak terdapat di daerah dataran rendah. Dampak lain dari pola desa yang memusat adalah pola kekerabatan masyarakatnya yang sangat tinggi karena jarak antar rumah yang dekat sehingga interaksi antar individu menjadi lebih intens; b) Pola Tersebar atau Dispersed, yaitu pola desa tersebar memiliki ciri pemukiman yang tidak merata di satu titik tetapi menyebar ke segala penjuru desa. Pola desa seperti ini banyak terdapat di daerah pegunungan. Beberapa faktor yang memengaruhi pola desa ini adalah perbedaan tingkat kesuburan tanah, ketersediaan air tanah dan topografi; c) Pola Memanjang atau Linier, yaitu pola desa memanjang memiliki ciri pemukiman yang berada disamping jalan, rel kereta, pantai atau sungai. Masyarakat cenderung memilih pemukiman di dekat akses transportasi agar memudahkan mobilitas sehari-hari. Khusus desa yang berada di daerah sekitar pantai, masyarakatnya mayoritas bermata pencaharian sebagai nelayan.

Menurut Acwin (2003), penerapan konsep Sanga Mandala, ada 3 macam pola tata ruang:

a) Pola Perempatan (Catus Patha). Pada Pola Perempatan, jalan terbentuk dari perpotongan sumbu kaja - kelod (utara-selatan) dengan sumbu kangin-kauh (timur-barat). Berdasarkan konsep Sanga Mandala, pada daerah kajakangin diperuntukan untuk bangunan suci yaitu pura desa. Letak Pura Dalem (kematian) dan kuburan desa pada daerah kelod-kauh (barat daya) yang mengarah ke laut. Peruntukan perumahan dan Banjar berada pada peruntukan madya (barat-laut);

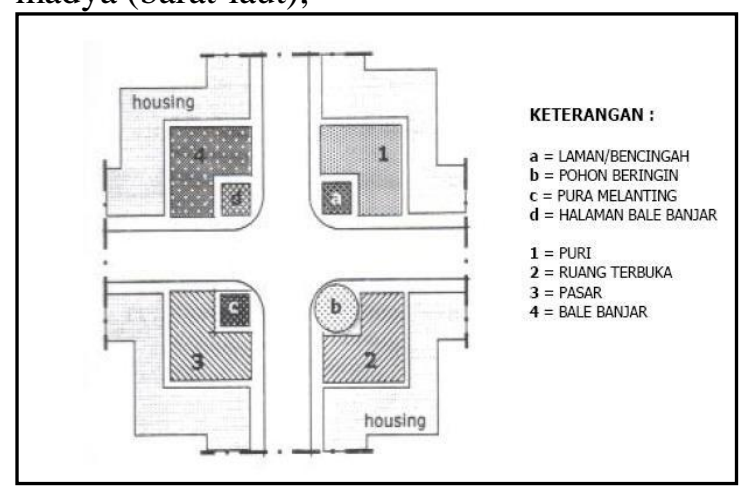

Gambar 4. Pola Permukiman Catus Patha Sumber : Acwin ,2003 b) Pola Linier, pada pola linier konsep Sanga Mandala tidak begitu berperan. Orientasi kosmologis lebih didominasi oleh sumbu kajakelod (utara-selatan) dan sumbu kangin-kauh (timur-barat). Pada bagian ujung Utara perumahan (kaja) diperuntukan untuk Pura (pura bale agung dan pura puseh). Sedang di ujung selatan (kelod) diperuntukan untuk Pura Dalem (kematian) dan kuburan desa. Diantara kedua daerah tersebut terletak perumahan penduduk dan fasilitas umum (bale banjar dan pasar) yang terletak di plaza umum. Pola linier pada umumnya terdapat pada perumahan di daerah pegunungan di Bali, dimana untuk mengatasi geografis yang berlereng diatasi dengan terasering;

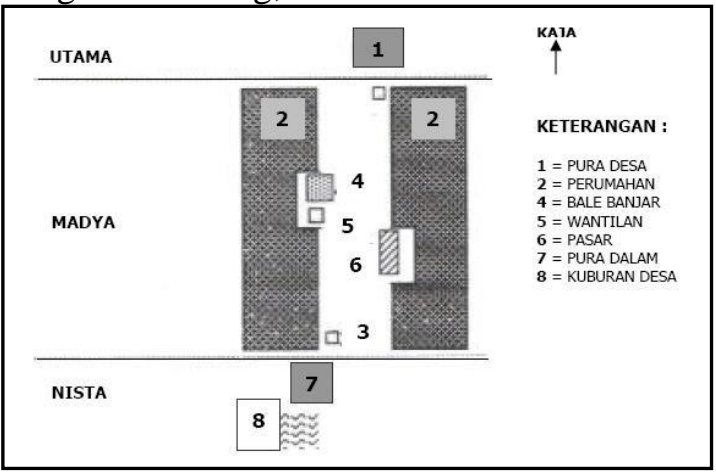

Gambar 5. Pola Permukiman Linier Sumber : Acwin, 2003

c) Pola Kombinasi, pada pola kombinasi paduan antara pola perempatan (Catus patha) dengan pola linier. Pola sumbu perumahan memakai pola perempatan, namun demikian sistem peletakan elemen bangunan mengikuti pola linier. Peruntukan pada fasilitas umum terletak pada ruang terbuka (plaza) yang ada di tengah-tengah perumahan. Lokasi bagian sakral dan profan masing-masing terletak pada ujung utara dan selatan perumahan. 


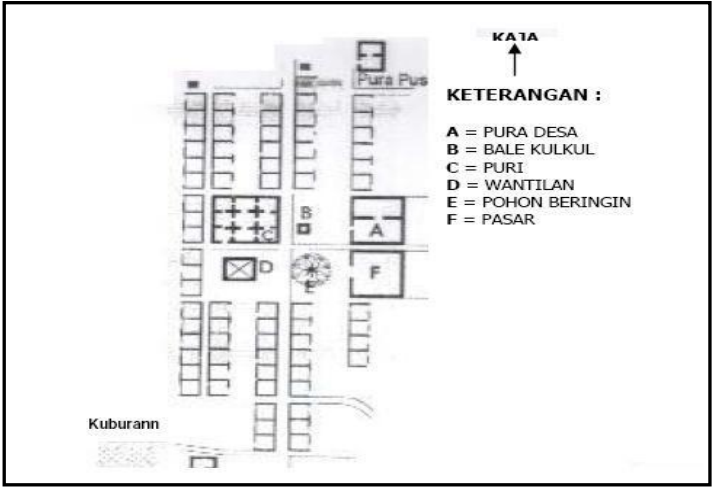

Gambar 6. Pola Permukiman Kombinasi Sumber : Acwin , 2003

Berdasar tiga pola keruangan desa menurut $\mathrm{R}$. Bintarto dan tiga pola ruang desa di Bali menurut Acwin, dan berdasar observasi di lapangan, terbentuknya pola ruang Desa Penglipuran merujuk ke Pola Linier. Pada pola linier konsep Sanga Mandala tidak begitu berperan. Orientasi kosmologis lebih didominasi oleh sumbu kaja-kelod (utaraselatan) dan sumbu kangin-kauh (timur-barat). Pada bagian ujung Utara perumahan (kaja) diperuntukan untuk Pura (pura bale agung dan pura puseh). Sedang di ujung selatan (kelod) diperuntukan untuk Pura Dalem (kematian) dan kuburan desa. Diantara kedua daerah tersebut terletak perumahan penduduk dan fasilitas umum (bale banjar dan pasar) yang terletak di plaza umum. Pola linear ini terbentuk karena Desa Penglipuran berada dekat dengan wilayah pegunungan menyebabkan bentuk lahan desa ini berlereng menurun ke arah selatan.

\subsection{Rumah Tradisional Desa Penglipuran}

Desa Penglipuran memiliki 76 kavling pekarangan dan rumah tempat bermukim warga terbagi dalam dua jajaran yaitu di Barat 38 rumah dan di Timur 38 rumah. Banyaknya jenis komposisi rumah dalam satu unit rumah di desa Penglipuran, setiap satu unit bangunan bisa terdapat 4 bangunan pokok, dan sisanya bisa lebih tergantung jumlah anggota keluarga. Yang menjadi perbedaan adalah posisi rumah bagian Barat dan Timur bagi setiap yang memasuki Gapura Depan. Untuk rumah bagian Timur jika masuk gapura akan langsung bertemu dengan omah, sedang bagian Barat ketika memasuki gapura kita akan langsung bertemu dengan pura tempat sembahyang. Posisi pola ruang yang berbeda pada setiap rumah bagian Barat dan Timur tersebut terjadi karena pola rumah di Desa Penglipuran menggunakan Pola Dasar Nawa Sanga, yaitu penggabungan orientasi antara gunung dan laut (Utara-Selatan), serta terhadap peredaran terbit terbenamnya matahari (Timur-Barat). Pola ruang rumah tinggal Desa Penglipuran menganut sistem nilai ruang utama pada sumbu religi berada di timur (matahari terbit) dan nilai ruang nista berada di barat (matahari terbenam). Oleh karenanya penataan pola ruang rumah tinggal di Desa Penglipuran yang memiliki beberapa gugusan bangunan, terletak sejajar dengan orientasi linier yang dibagi oleh rurung gede (jalan besar) yang menghadap ke arah Timur dan ke arah Barat.

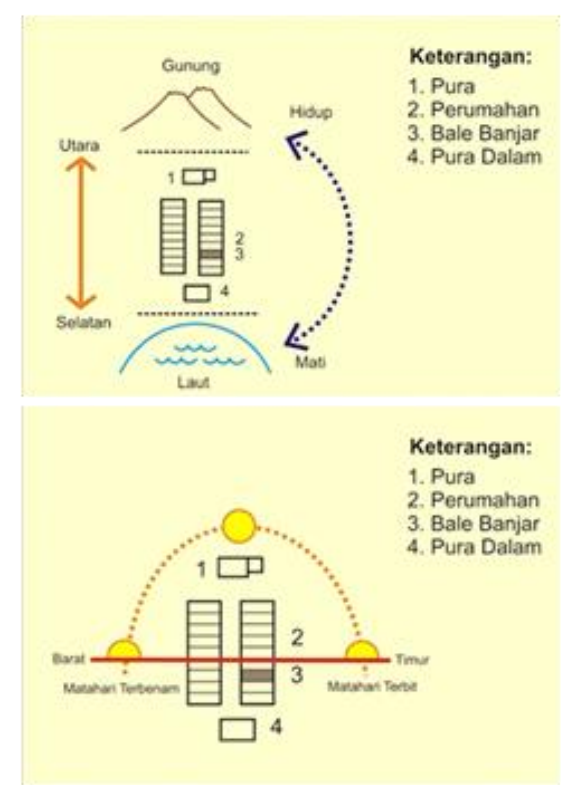

Gambar 7. Pola Dasar Nawa Sanga Di Desa Penglipuran

Sumber : @KoranArsitektur

Tatanan ruang pekarangan perumahan yang menghadap ke arah Timur tersusun sebagai berikut: Angkul-angkul (gapura), natah (halaman), dengan sisi Utara terdiri dari tiga komponen bangunan yaitu: Tempat Suci (Merajan/Sanggah), Paon (dapur) dan Bale Sakenem (Loji). Sisi Selatan terdapat bangunan: Bale Dangin (Bale Adat). Di sisi Barat dari halaman pemukiman adalah Tebe (Halaman belakang). Sedangkan Tatanan ruang pekarangan perumahan yang menghadap ke arah Barat tersusun kebalikan dari pekarangan perumahan yang menghadap ke Timur. 


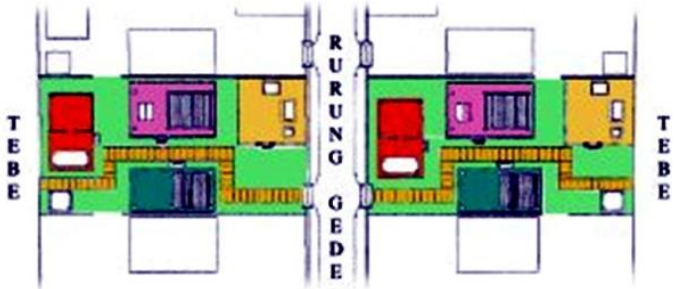

Gambar 8. Denah Rumah Tradisional Desa Panglipuran

Berikut ini merupakan bagian-bagian dari Rumah Tradisional Penglipuran Bali dan fungsinya yaitu: 1) Merajan; Tempat sembahyang keluarga, terdiri atas beberapa pelinggih (bangunan suci), fungsinya untuk tempat ibadah dan pemujaan leluhur. 2) Bale Dangin; berfungsi sebagai tempat untuk mempersiapkan kegiatan upacara keagamaan (terutama upacara manusia yadnya dan pitra yadnya). Pada saat tidak ada upacara, Bale Dangin dimanfaatkan sebagai tempat tidur untuk anak laki-laki. (Acwin, 2008). Bale Dangin ini memiliki pondasi yang berukuran 50 centimeter hingga satu meter dari permukaan tanah. 3) Paon (dapur); Tempat memasak dan menyiapkan makanan, bentuknya mirip dengan dapur tradisional Jawa yang masih menggunakan kayu bakar, saat upacara pernikahan paon juga digunakan untuk tempat mempelai pengantin makan bersama. 4) Bale Sakenem; Sakenem berarti saka: tiang dan enem: enam (bale bertiang enam), tempat tinggal kepala keluarga, dan mereka yang sudah menikah, terdiri dari bangunan tertutup dan bagian teras terbuka. 5) Angkul-angkul; Adalah salah satu dari beberapa bentuk pamesuan/gapura masuk rumah di Bali, yang merupakan satu unit umah atau pintu pekarangan untuk unit bangunan. Angkulangkul pada setiap rumah di Desa Penglipuran berdiri dengan model dan bentuk serta bahan yang sama. Pondasi angkul-angkul terbuat dari tanah dan batu padas dengan sedikit semen. Bahan dasar dari angkul-angkul terbuat dari batu bata. Atap angkul-angkul menggunakan bambu yang mudah didapatkan di desa Panglipuran dan selaras dengan batu bata.

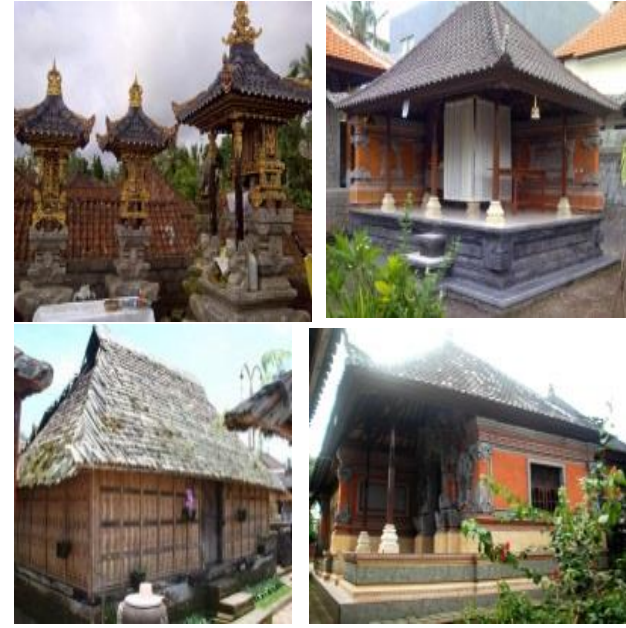

Gambar 9. Merajan; Bale Daengin; Paon; Bale Sakenem

Pada mulanya permukiman adat Desa Penglipuran hanya merupakan permukiman yang berada dipinggir (sepanjang) poros utama desa. Pada sisi Barat dan Timur aksis linier ini membentang pekarangan warga yang masing-masing memiliki luas yang sama yaitu sikut satak (2,5 are). Sedangkan wilayah lainnya masih merupakan kawasan tak terbangun yang berupa hutan dan tegalan termasuk lahan dibelakang pekarangan sikut satak tersebut.

Pada lingkup kawasan ruang sikut satak tersebut terbangun beberapa bangunan tradisional yang menjadi ciri khas Desa Adat Penglipuran yaitu: Dapur Tradisi Penglipuran, terletak di sebelah Utara dan sekaligus sebagai tempat tidur bagi yang sudah jompo, Bale Sakenem, terletak di sebelah Selatan sebagai tempat upacara yadnya (manusia yadnya, pitra yadnya, dll), dan Loji, terletak di sebelah Barat sebagai tempat tidur keluarga, tempat menerima tamu dan ruang bermain anak-anak.

\subsection{Struktur Rumah Tradisional Desa Penglipuran}

Desa Adat Penglipuran menggunakan bahan bangunan alami yang dapat diambil dari lingkungan mereka sebagai bahan bangunan utamanya. Material alami tersebut banyak terlihat pada bangunan-bangunan tradisional pada desa (Dwijayasastra, 2013). Rumah Tradisional Bali kebanyakan dibuat dari material organik seperti kayu, bambu, ilalang, dan serat tanaman (Julian; 2014). Hasil pengamatan lapang pada rumah tinggal dan 
studi pustaka menyimpulkan pemilihan material yang seragam terdapat pada hunian mereka. Rumah panggung pada rumah Bali sudah digantikan oleh pelataran dari bata, mirip dengan bagian pelataran pada candi (Sopandi, 2013). Pertemuan tiang dan balok kayu pada bangunan di Desa Penglipuran Bali, karakter balok biasanya tidak berhenti tepat di kolom, tetapi dibuat lebih panjang (extend) sekitar 10 $\mathrm{cm}$ dari tiang. Menurut Prijotomo (2017: halaman 78) memang dengan sambungan tiang dan balok dengan system purus dan lubang itu konstruksi tidak menjadi kaku dan rigid, tetapi dalam kenyataannya tetap kuat dan kokoh.

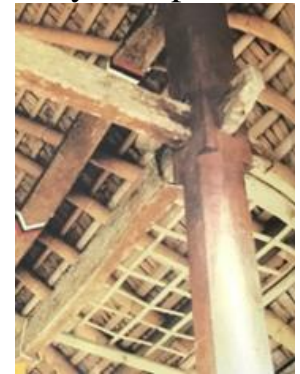

Gambar 10. Tiang dan Balok

Struktur dan konstruksi beserta bahan bangunan yang digunakan oleh kebanyakan masyarakat di Desa Penglipuran adalah sebagai berikut:

1) Bebaturan; Bangunan Tradisional Bali yang memiliki prinsip kepala-badan-kaki (Utama, Madya, Nista). Maka bagian-bagiannya pada setiap bangunan adalah dimulainya dari bebaturan, yaitu bagian bawah atau kaki bangunan. Bebaturan terdiri dari jongkok asu sebagai pondasi tiang dan tapa sujan sebagai perkerasan tepi bebaturan. Namun bisa juga dikatakan, bebaturan itu merupakan lantai bangunan, undag, atau tangga lintasan naik turun ke lantai halaman. Menurut Wijaya (2002), kehadiran bebaturan dengan sopan akan memisahkan level antara bangunan dengan taman, hewan, atau hal-hal lain yang bersifat kotor dan bebas berkeliaran.

2) Dinding; Dinding untuk bangunan yang sederhana bidang-bidang pembatas sisi dipakai dinding gedeg anyaman bambu atau anyaman daun kelapa yang disusun dengan rangka terampa uger-uger. Daun kelapa dapat dianyam pada kedua belah sisi sebelah sehingga mendapatkan anyaman yang lebih tebal dan lebih kokoh dari teratub yang disebut kelangsah. Pemasangan penutup dinding pada rangka dinding diikat dengan tali bambu atau tali ijuk dalam satu komposisi yang serasi.

3) Tembok; Tembok dan pilar-pilarnya dibangun dengan pola kepala-badan-kaki, dihiasi dengan pepalihan dan ornament bagianbagian tertentu. Tembok tradisional dibangun terlepas tanpa ikatan dengan kontruksi rangka bangunan. Dipertegas dengan celah antara kepala tembok dan sisi bawah atap sehingga tembok bebas tidak memikul. Dengan kontruksi tembok bebas beban diharapkan terhindar dari bahaya.

4) Sesaka atau Kolom; Elemen kontruksi utama dalam bangunan tradisional adalah tiang, modul dasar sesungguhnya. Tiang disebut juga sesaka. Jarak tiang ke tiang ke arah panjang adalah sepanjang tiang ditambah pengurip (pelebih). Jarak tiang ke tiang ke arah lebar 2/3 panjang tiang ditambah pengurip. Dan bahan yang dipakai untuk sesaka adalah kayu-kayu dengan kualitas dari kelompok-kelompok tertentu seperti raja kayu ketwel, patih kayu jati, selain itu digunakan pula raja kayu cendana, patih kayu menengen. Bangunanbangunan tradisional yang dibangun dengan konstruksi rangka sesaka dan bagian-bagian rangka lainnya hubungan elemen-elemen strukturnya dikerjakan dengan sistem lait, baji dan ikatan tali temali. Struktur dan kontruksi serupa itu merupakan struktur dan kontruksi yang tahan gempa yang diperlukan untuk bangunanbangunan didaerah yang sering terjadi gempa.

5) Penentang; Balok belandar sekeliling rangkaian tiang-tiang tepi, dalam bangunan tradisional disebut lambang dan yang diatas disebut sineb. Balok tank yang membentang ditengah-tengah mengikat jajaran tengah disebut penentang.

6) Iga-iga; Usuk-usuk bangunan tradisional Bali disebut juga iga-iga. Pangkal iga-iga dirangkai dengan kolong atau dedalas yang merupakan bingkai tepi luar atap. Ujung atasnya menyatu dengan puncak atap. Batang simpul menyatu dipuncak disebut petaka untuk atap berpuncak satu titik dan dedeleg untuk puncak memanjang. Disebut langit-langit untuk atap dengan kontruksi kampiyah yang bukan limasan. 


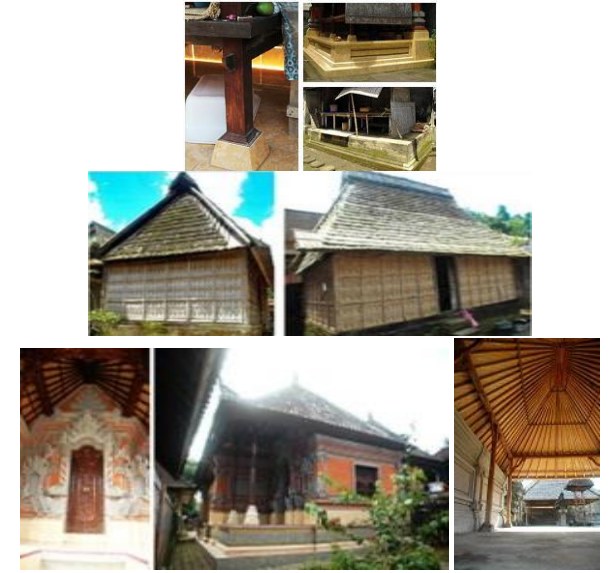

Gambar 11. Bebaturan; Dinding; dan Raab

7) Raab; Raab penutup atap tradisional disebut raab yang umumnya dibuat dari bahan-bahan alam, sebagian besar alang-alang. Di pegunungan ada pula yang dibuat dari sirap bambu seperti yang terdapat di desa panglipuran ini. Alang-alang dihasilkan sekali dalam setahun untuk bahan yang cukup tua. Disabit dibersihkan, diolah dalam rangkaian ikatan yang merupakan bidang-bidang atap. Ikatan alang-alang dengan tali ijuk dan ke bidang rangka atap diikatkan dengan tali bambu pada iga-iga yang juga terdapat dari bambubambu pilihan.

\subsection{Kearifan Lokal Desa Panglipuran}

Di Desa Penglipuran, untuk mengatur semua tata cara pembangunan ada sebuah kaidah arsitektur yang dianut dan disebut dengan nama awig-awig. Awig-awig ini adalah merupakan perwujudan kearifan lokal yang menjadi landasan kuat dalam pengelolaan sumber daya alam dan lingkungan yang baik. Awig-awig ini pada dasarnya adalah hukum adat berupa peraturan atau undang- undang yang disusun dan ditetapkan oleh anggota masyarakat desa, banjar, dan subak tentang aturan tata kehidupan masyarakat di bidang agama, budaya, dan sosial-ekonomi di Bali. Permukiman penduduk Desa Penglipuran yang terletak di tengah wilayah, terdiri atas 76 pekarangan dengan arah melintang utara selatan (kaja-kelod) yaitu pada jalur barat dan timur.

Desa Adat Penglipuran merupakan salah satu desa adat yang dilestarikan dan dijaga kealamiannya, baik itu dari segi kebersihan, lingkungan, serta adat istiadat untuk tetap menjaga keasrian dan keharmonisan antara manusia dan alam. Desa Adat Penglipuran, merupakan salah satu desa adat terbersih nomor 3 di dunia menurut Unesco, dilihat dari kebersihan, fungsi sarana dan prasarana, juga tidak adanya polusi, karena di desa ini tidak ada yang menggunakan kendaraan sekalipun misalkan seperti motor, apalagi mobil. Desa Adat Penglipuran merupakan sebuah lanskap tradisional yang menempatkan unsur alam sebagai konsep dasar rancangannya dan memiliki bentuk kearifan local arsitektur berkelanjutan. Untuk mencapai kondisi berkelanjutan muncullah pemikiran-pemikiran dan pendekatan-pendekatan baru dalam desain diantaranya desain ekologis (ecological design), desain berkelanjutan secara ekologis (ecologically sustainable design), desain hijau (green design), dan lainnya adalah istilah-istilah yang menggambarkan penerapan prinsipprinsip keberlanjutan dalam merancang bangunan maupun lanskap (Kibert 2008). Menurut Parimin (1986) Desa Adat Penglipuran merupakan salah satu desa tradisional di Bali yang disebut sebagai Bali Aga (Bali Mula/Bali Kuna). Pada umumnya Bali Aga merupakan desa tradisonal yang masyarakatnya tidak menganut sistem kasta seperti pada umumnya masyarakat di Bali. Pendeta tertinggi tidak melakukan upacara padiksan dan kepemimpinan desa umumnya menganut pola kembar ataupun kolektif, berdasarkan sistem hulu apad atau senioritas. . Hal menarik dari Desa Adat Penglipuran adalah pada pola ruang dan rumah adatnya yang memiliki ruang terbuka cukup luas memanjang dari utara ke selatan untuk membagi desa menjadi dua bagian. Ruang terbuka itu pada umumnya dilapisi batu, bagian yang tinggi mendekati pegunungan atau bukit. Hasil observasi lapangan menunjukkan bahwa secara garis besar areal Desa Penglipuran terbagi atas tiga bagian besar, yaitu area permukiman/hunian penduduk yang terletak di tengah-tengah, area pertanian berupa tegalan (kebun dan ladang), dan area hutan bambu maupun hutan alami. Area pertanian banyak terdapat pada bagian tengah dan selatan desa diluar area inti desa. Letak Desa Adat Penglipuran yang berada dekat dengan wilayah pegunungan menyebabkan bentuk lahan desa ini berlereng menurun ke arah selatan dengan kemiringan rata-rata antara $10-45 \%$ dengan 
jenis tanah lempung berpasir, sehingga sangat cocok untuk area pertanian. (Hudyana; 2002).

\section{KESIMPULAN}

Potensi Desa Adat Penglipuran mengacu pada Konsepsi Tri Hita Karana sebagai sumber adanya keselamatan, kesejahteraan dan kebahagiaan yaitu : hubungan harmonis manusia dengan Tuhan, antara sesama manusia dan manusia dengan lingkungannya yang diimplementasikan wujudnya menjadi : 1) Parhyangan, merupakan unit lokasi kawasan suci dan tempat suci (pura) tertentu besar maupun kecil sebagai pengejawantahan unsur ke-Tuhanan-nya. 2) Pawongan, berarti masyarakat penghuni kawasan beserta keorganisasian tradisional yang ada sebagai perwujudan unsur manusianya (penghuninya). 3) Palemahan, bermakna wilayah dalam batasbatas definitif beserta unsur perumahan, pekarangan, lingkungan sebagai wujud proyeksi unsur alamnya.

Desa Penglipuran menganut konsep Tri Mandala, yakni sebuah sistem penataan ruang yang dibagi menjadi tiga zona peruntukan. Pembagian tata ruang berdasarkan konsep Tri Mandala adalah terdiri dari: 1) Utama Mandala (Ulu); 2) Madya Mandala (Tengah); 3) Nista Mandala (Teben).

Kondisi Desa Adat Penglipuran sebagai desa tradisional pegunungan memperlihatkan satu hal yang menonjol, yaitu persebaran pola pemukiman cenderung bersifat linier hanya sepanjang poros utama desa dan memperlihatkan pola desa tradisional pegunungan (pola linier).

Rumah Tradisional Penglipuran Bali merupakan suatu tatanan/bentuk hasil budaya pola pikir budaya nenek moyang masyarakat Penglipuran menata suatu kawasan dengan baik dan menjunjung tinggi adat leluhur dan mengupayakan menjaga tatanan tersebut dengan baik, rapi teratur berkonsep dan berkesinambungan alam dan lingkungan sekitar.

\section{REFERENSI}

Acwin Dwijendra, Ngakan Ketut (2003). Perumahan dan Permukiman Tradisional Bali. Jurnal Permukiman Natah Vol. 1.
Acwin Dwijendra, Ngakan Ketut (2008), Arsitektur Rumah Tradisional Bali. Udayana University Press, Denpasar.

Arrafiani (2012). Rumah Etnik Bali. Griya Kreasi, Jakarta.

Bintarto, R 1977. Suatu Pengantar Geografi Kota. Jakara : LP3ES.

Budiardjo, Eko (1986). Architectural Conservation in Bali. Gadjah Mada University Press, Yogyakarta.

Dwijayasastra, Nikko (2013). Kajian Arsitektur Hijau Desa Adat Penglipuran Bali. Departemen Arsitektur Lanskap IPB, Bogor.

Hudyana (2002). Tenget dalam pembangunan berkelanjutan studi kasus: revitalisasi kearifan lokal mengenai lingkungan di Desa Adat Penglipuran Bangli. Thesis Universitas Diponegoro, Semarang.

Julian, Davison (2014). Balinese Architecture. Tuttle Publishing,

Parimin, A. P. (1986). Fundamental Study on Spatial Formation of Island Village Enviironmental Herarchy of SacredProfane Concept in Bali, Disertation, Osaka University, Japan.

Prijotomo, Josef (2008). Pasang Surut Arsitektur Indonesia. Wastu Lanas Grafika, Surabaya.

Prijotomo, Josef (2017). Prijotomo Benahi Arsitektur Nusantara. Departemen Arsitektur ITS, Surabaya.

Tribinuka, Tjahja (2017). Sejarah Majapahit dan Hubungannya dengan Puri-puri di Bali serta Analisis Arsitekturnya. Abiyasa Nusantara, Surabaya.

Sopandi, Setiadi (2013). Sejarah Arsitektur Sebuah Pengantar. PT Gramedia Pustaka Utama, Jakarta.

Wira Kasuma, Putu Agus \& Iwan Suprijanto (2012), Karakteristik Ruang Tradisional Pada Desa Adat Penglipuran, Bali. Jurnal Permukiman Vol. 7 No. 1 April 2012: 4050. 